\title{
The Effect of Astaxanthin on Smoke Inhalation Injury on Rats: Experimental Study
}

\author{
Sıçanlarda Akciğer İnhalasyon Hasarı Üzerine Astaxanthinin Etkisi: Deneysel Çalışma
} ${ }^{1}$ Atacan Emre Kocman, ${ }^{1}$ Mert Secer, ${ }^{1}$ Cengiz Cetin, ${ }^{2}$ Cihan Tanrikut, ${ }^{2}$ Mehmet Cengiz Ustuner, ${ }^{3}$ Deniz Arik

Abstract

${ }^{1}$ Eskisehir Osmangazi University,

Department of Plastic, Reconstructive and

Aesthetic Surgery, Eskisehir, Turkey

${ }^{2}$ Eskisehir Osmangazi University,

Department of Medical Biology, Eskisehir, Turkey

${ }^{3}$ Eskisehir Osmangazi University, Department of Pathology, Eskisehir, Turkey

Correspondence:

Mert SECER

Eskisehir Osmangazi University,

Department of Plastic,

Reconstructive and Aesthetic

Surgery, Eskisehir, Turkey

e-mail: mertsecer@gmail.com
Smoke inhalation damage defined as mucosal damage in the respiratory system caused by flames, hot air, steam, toxic gas and particulate matter in smoke. Oxidative stress is an important mechanism, as high temperature smoke contains a high concentration of strong oxidants. The resultant inflammatory response, if uncontrolled, causes abundant inflammatory cell accumula-tion in the lungs, producing excessive reactive oxygen species (ROS) and inducing oxidative stress injury. A total of forty adult male Sprague-Dawley albino rats were used. Sham group (n:8) was kept in smoke study room for 28 min without giving any injury and treatment. Control group (n:8); the dorsum of rats was shaved and surgically scrubbed. After receiving $30 \%$ burn injury they received four series of smoke and four series of $100 \%$ oxygen between smoke inhalations. ASX groups; after receiving $30 \%$ burn injury the same inhalation injury protocol was applied to these groups. After exposure to smoke and burn injury, ASX10 (n:8) animals received $10 \mathrm{mg} / \mathrm{kg} / \mathrm{d}$ astaxanthin, ASX30 (n:8) animals received $30 \mathrm{mg} / \mathrm{kg} / \mathrm{d}$ astaxanthin, ASX100 (n:8) animals received $100 \mathrm{mg} / \mathrm{kg} / \mathrm{d}$ astaxanthin dissolved in $5 \mathrm{ml}$ of olive oil for 3 days with orogastric route. For histopathologic examination, samples were taken from trachea, and mid-portion of parenchyma. For biochemical analysis, samples taken from the right lower lobes and stored at $-80^{\circ} \mathrm{C}$. Histologic assessment of alveolar congestion and neutrophilic infiltration were statistically increased in group control than ASX10, ASX30 and ASX100 groups. Histologic assessment of haemorrhage and alveolar wall thickness was increased in group control than ASX30 and ASX100 groups. 4-HNE and NF-к $\beta$ levels in control group was significantly increased than ASX10, ASX30 and ASX100 groups. Proinflammatory cytokines TNF- $\alpha$, IL- 6 and IL- $1 \beta$ levels in lung tissue decreased by astaxanthin treatment at doses of $30 \mathrm{mg} / \mathrm{kg} / \mathrm{d}$ and $100 \mathrm{mg} / \mathrm{kg} / \mathrm{d}(\mathrm{p}<0,05)$. Oxidative stress marker MDA levels and GR levels in lung tissue decreased by astaxanthin treatment $(\mathrm{p}<0,05)$. Our results have demonstrated that astaxanthin use have a beneficial role in smoke inhalation injury accompanying $30 \%$ tbsa burn of rats. Thus, astaxanthin may represent a potential approach to prevent systemic response due to oxidative stress and inflammatory processes of smoke inhalation injury and $>30 \%$ burns.

Keywords: Astaxanthin; inhalation burn; smoke inhalation; burns
Respiratuar sistemde, sıcak hava, alev, toksik gazlar ve partiküllerin yarattığı mukozal hasarı tanımlamak için inhalasyon hasarı terimi kullanılmaktadır. Yüksek sıcaklıktaki duman yüksek konsantrasyonda güçlü oksidanlar içermekte ve oksidatif stres yaratarak oluşan hasarda rol oynamaktadır. Olușan inflamatuar cevap kontrol edilemezse, akciğerlerde abondan inflamatuar hücre birikimine, reaktif oksijen radikalleri üretimine ve oksidatif stres yaralanmasına yol açmaktadır. 40 adet erişkin erkek Sprague -Dawley albino rat kullanılarak gerçekleştirilen deneyde, Sham grubu $(n: 8)$ duman odasında 28 dakika boyunca herhangi bir yaralanma veya tedavi meydana getirmeden tutuldu. Kontrol grubunda (n:8) ratların sırtı tıraşlanarak cerrahi usullere uygun șekilde örtüldü. $\% 30$ oranında yanık oluşturulduktan sonra 4 seri halinde duman inhalasyonu ve bunların aralarında \%100 oksijen uygulaması yapıldı. ASX uygulanan gruplarda ise, \%30 yanık oluşturulduktan sonra aynı inhalasyon hasarı protokolu uygulandı. Yanık ve inhalasyon hasarına uğratıldıktan sonra ise, ASX10 (n:8) rata $10 \mathrm{mg} / \mathrm{kg} /$ gün astaxantin, ASX30 (n:8) rata $30 \mathrm{mg} / \mathrm{kg} / \mathrm{gün}$ astaxantin, ASX100 (n:8) rata $100 \mathrm{mg} / \mathrm{kg} /$ gün astaxantin $5 \mathrm{ml}$ zeytinyağı içinde çözülmüş olarak orogastrik yoldan 3 gün boyunca verildi. Histopatolojik inceleme için trakea ve akciğer parankiminin orta lobundan örnekleme yapıldı. Biyokimyasal analiz için ise sağ alt akciğer loblarından örnek alınarak $-80^{\circ} \mathrm{C}$ 'de muhafaza edildi. Alveoler konjesyon ve nötrofilik infiltrasyonun histopatolojik bulguları ASX10, ASX30 ve ASX100 gruplarıyla kıyaslandığında kontrol grubunda istatistiksel olarak anlamlı ölçüde yüksek görüldü. Hemoraji ve alveoler duvar kalınlaşması kontrol grubunda, ASX30 VE ASX 100 gruplarına kıyasla artmıs olarak saptandı. 4-HNE ve NF-к $\beta$ değerleri kontrol grubunda, ASX10, ASX30 ve ASX100 gruplarına oranla anlamlı oranda yüksek bulundu. TNF- $\alpha$, IL-6 ve IL-1 $\beta$ gibi pro-inflamatuar sitokin düzeyleri $30 \mathrm{mg} / \mathrm{kg} / \mathrm{gün}$ ve $100 \mathrm{mg} / \mathrm{kg} /$ gün astaxantin ile tedavi edilen grupta anlamlı olarak düsük bulundu ( $\mathrm{p}<0,05)$. Akciğer dokusundaki oksidatif stress markerlarından MDA ve GR düzeyleri astaxantin ile tedavi edilen grupta anlamlı ölçüde düşük bulundu $(\mathrm{p}<0,05)$. Sonuç olarak, vücut yüzey alanının \%30’u yanan ve eş zamanlı akciğer inhalasyon hasarı oluşturulan sıçanlarda astaxantin kullanımının tedavide olumlu etkileri olduğu görüldü. Astaksantinin oksitadif stres ve inflamasyona bağlı oluşan sistemik cevabın tedavisinde olumlu yönleri olduğu görülmüştür.

Anahtar Kelimeler: Astaksantin; inhalasyon yanı̆̆ı; duman inhalasyonu; yanık

Received 16.04.2021 Accepted 25.10.2021 Online published 02.11.2021 


\section{Introduction}

Smoke inhalation damage defined as mucosal damage in the respiratory system caused by flames, hot air, steam, toxic gas and particulate matter in smoke (1). The major cause of morbidity and mortality in victims of fires are respiratory complications (2). Smoke inhalation injury is mainly caused by three mechanisms. These mechanisms are heat, particles in smoke and pulmonary irritants which cause systemic toxicity (3). The resultant inflammatory response may cause higher fluid resuscitation volumes, progressive pulmonary dysfunction, prolonged ventilator days, increased risk of infections and acute respiratory distress syndrome (ARDS) (4). Smoke inhalation is an independent factor affecting mortality in burn patients and increases it alone by $20 \%$ in cases accompanied by burns (5). Even if there is no inhalation injury, patients with severe burns are at high risk of respiratory failure. This may occur as an isolated event or as a component of multiple organ system failure initiated by systemic infection (6).

Oxidative stress is an important mechanism, as high temperature smoke contains a high concentration of strong oxidants. (7). The oxidants leads to cellular DNA damage, ATP deficiency and cell necrosis. Histological features of burn injury include interstitial oedema, hyaline membrane formation and neutrophil sequestration in the lung. Fibrinogens activated by neutrophil sequestration and inflammatory mediators accumulate in airways to form obstruction and cause ventilation / perfusion incompatibility $(3,8)$. Based on the complex pathogenesis of smoke inhalation injury, drugs with different mechanisms of action such as bronchodilators, anticoagulants, antioxidants, and corticosteroids have been investigated (9). Astaxanthin (ASX), a potent antioxidant, pinkishred pigment and member of xanthophile family with a ketocarotenoid structure. Carotenoids such as zeoxanthine, lutein and beta-carotene have many common points with ASX in metabolic and physiological aspects. Furthermore, the bioactivity and antioxidant properties of ASX is much higher due to the presence of keto- and hydroxy- groups at both ends of the molecule (10). The use of astaxanthin dose dependently for smoke inhalation injury has been investigated because it has the potential to reduce oxidative stress and anti-inflammatory features (11).

\section{Material and Methods}

\section{Animals}

A total of forty adult male Sprague-Dawley albino rats (mean body weight: $300 \pm 30 \mathrm{~g}$ ) were used. The study protocol was approved by the Animal Experiments Local Ethics Committee of Eskisehir Osmangazi University (492-2) and was supported by Eskişehir Osmangazi University Scientific Research Projects Commission with project number 2017-1477. Rats were randomly divided into 5 groups (Sham: 8, Control: 8, ASX10mg: 8, ASX30mg: 8, ASX100mg: 8). The animals were caged separately and environment was maintained at room temperature with a 12-h light/dark cycle. Standard laboratory food for rats and water were provided to the animals.

\section{Experimental Protocol}

All surgical procedures were performed by the same surgeon under general anaesthesia with intraperitoneal thiopental (Pental ${ }^{\circledR}$ Sodium 0.5g, I.E. ULAGAY, Istanbul) $50 \mathrm{mg} / \mathrm{kg}$ injection. Sham group was kept in smoke study room for 28 min without giving any injury and treatment. For control group, the dorsum of rats was shaved and surgically scrubbed. To produce the burn, a hot metal plate was heated with a Bunsen burner for $2 \mathrm{~min}$, and then held in placed on the rats back for $10 \mathrm{~s}$ (12). After receiving 30\% burn injury they received four series of smoke and four series of $100 \%$ oxygen between smoke inhalations. Each smoke exposure was $3 \mathrm{~min}$ and each oxygen exposure was $4 \mathrm{~min}$. (13). We determine the ASX oral administration dosages which leads systemic antioxidant effect from previous studies (11). ASX groups after receiving 30\% burn injury were kept in smoke room. The same inhalation injury protocol was applied to these groups. After exposure to smoke and burn injury, ASX10 animals received $10 \mathrm{mg} / \mathrm{kg} / \mathrm{d}$ astaxanthin, ASX30 animals received $30 \mathrm{mg} / \mathrm{kg} / \mathrm{d}$ astaxanthin, ASX100 animals received $100 \mathrm{mg} / \mathrm{kg} / \mathrm{d}$ astaxanthin dissolved in $5 \mathrm{ml}$ of olive oil for 3 days with orogastric route. Fluid resuscitation during the experiment was carried out using Ringer's lactate solution following the formula: 4 $\mathrm{ml} / \%$ burned body surface area $/ \mathrm{kg}$ body weight for the first $24 \mathrm{~h}$, and $2 \mathrm{ml} / \%$ burned body surface area/kg body weight/day for the next $48 \mathrm{~h}$ (14). One half of the volume for the first day was 
infused in the initial $8 \mathrm{~h}$, and the rest was infused over the next $16 \mathrm{~h}$. After the experiment, the rats were returned to their cages at normal room temperature and atmosphere. At the end of $72 \mathrm{~h}$, the rats were sacrificed under deep anaesthesia (thiopental $100 \mathrm{mg} / \mathrm{kg}$ i.m.). The abdomen was opened; the diaphragm was incised to allow the lungs to collapse. By a midline sternal incision thorax was opened, and the lungs were rapidly removed en bloc along with the trachea. For histopathologic examination, samples were taken from trachea, and mid-portion of parenchyma. For biochemical analysis, samples taken from the right lower lobes and stored at $-80^{\circ} \mathrm{C}$.

\section{Histopathology}

Lungs were harvested for observing morphologic alterations. The right middle lobes of the lungs were fixed with $10 \%$ formalin, embedded in paraffin, and sectioned to $4 \mu \mathrm{m}$ thickness. After deparaffinization and rehydration, the sections were stained with hematoxylin and eosin. The pathological sections were observed in a blinded fashion. Pathological injury score was evaluated blindly according to Mikawa's method (15). Pathological scores (lung damage) were evaluated by (a) alveolar congestion; (b) haemorrhage; (c) neutrophilic infiltration and (d) thickness of the alveolar wall / hyaline membrane formation. Each item was graded on a 5-point scale ( 0 , minimal damage; 1 , mild damage; 2 , moderate damage; 3 , severe damage; 4 , maximal damage) (16).

\section{Immunohistochemical analysis of $\mathrm{NF}-\kappa \mathrm{B}$ and 4-hydroxynonenal}

Paraffin-embedded sections $4-\mu \mathrm{m}$ in thickness were stained for nuclear factor $\kappa \mathrm{B}(\mathrm{NF}-\kappa \mathrm{B})$ and cytoplasmic 4-hydroxynonenal (4-HNE) immunohistochemically. The immunohistochemical experiments were performed according to the manufacturer's recommendations. Briefly, the dewaxed or PBSwashed tissue sections were cultured in 3\% hydrogen peroxide to eliminate intrinsic peroxidase and quenched in normal goat serum for $30 \mathrm{~min}$. The sections were then incubated at 4 ${ }^{\circ} \mathrm{C}$ overnight with polyclonal rabbit anti-rat NF$\kappa \mathrm{B}$ or 4-hydroxynonenal antibody, followed by addition of the anti-rabbit immunoglobulin and streptavidin conjugated to horseradish peroxidase. Finally, 3, 3'-diaminobenzidine was used for colour development, and hematoxylin was used for counterstaining. Brown staining in cytoplasm and/or nucleus was taken as a positive indicator for expression. The results were evaluated semi-quantitatively according to percentage of positive cells.

\section{Biochemical Measurements}

The right base lobe of lung tissues was harvested and immediately homogenized on ice-surface in 5 volumes of normal saline. The homogenates were centrifuged at $1200 \mathrm{rpm} / \mathrm{min}$ for $10 \mathrm{~min}$. The glutathione reductase (GR), malondialdehyde (MDA), interleukin 6 (IL-6), interleukin $1 \beta$ (IL-1 $\beta$ ) and tumour necrosis factor $\alpha$ (TNF- $\alpha$ ) content in the supernatants were respectively measured using GR, MDA, IL_6, IL1 $\beta$ and TNF- $\alpha$ assay kits (Elabscience).

\section{Statistical Analysis}

The Shapiro Wilk test was used to investigate the suitability of data to normal distribution. In the comparison of the groups with normal distribution, independent sample t-test analysis was used for the two parameters and the one-way ANOVA was used for the groups with three parameters or more. In comparison of the groups which do not conform to normal distribution, Mann-Whitney $U$ test was used for the two parameters and Kruskal-Wallis $H$ test was used for the three parameters or more. IBM SPSS Statistics 21.0 (IBM Corp. Released 2012. IBM SPSS Statistics for Windows, Version 21.0. Armonk, NY: IBM Corp.) was used in the implementation of the analyses. A p value below 0.05 was considered as a criterion for statistical significance.

\section{Results}

\section{Histopathologic findings}

Histologic assessment of alveolar congestion and neutrophilic infiltration were statistically increased in group control than sham, ASX10, ASX30 and ASX100 groups $(\mathrm{p}<0,05)$ while there were no statistically difference between sham, ASX10, ASX30 and ASX100 groups. Histologic assessment of haemorrhage was increased in group control than sham, ASX30 and ASX100 groups $\mathrm{p}(<0,05)$ while there were no difference between sham, ASX10, ASX30 and ASX100 groups. Histologic assessment of thickness of alveolar wall was increased in group control than ASX30 and ASX100 $\mathrm{p}(<0,05)$, increased wall 
thickness also observed in ASX10 group than difference between sham, ASX30 and ASX100 ASX30 group $\mathrm{p}(<0,05)$, while there were no groups (Table 1) (Fig.1).

Table 1. Histopathologic and immunohistochemical findings with statistical analyses

\begin{tabular}{|c|c|c|c|c|}
\hline & & Mean \pm Std. Dev. & $\mathbf{p}$ & $\begin{array}{c}\text { Multiple } \\
\text { Comparisons }\end{array}$ \\
\hline Alveolar congestion & $\begin{array}{l}\text { Sham (1) } \\
\text { ASX } 10(2) \\
\text { ASX } 30(3) \\
\text { ASX } 100(4) \\
\text { Control (5) }\end{array}$ & $\begin{aligned} 1.13 & \pm 0.35 \\
1.13 & \pm 0.35 \\
1 & \pm 0 \\
1.13 & \pm 0.35 \\
1.75 & \pm 0.71\end{aligned}$ & $<0,05$ & $\begin{array}{l}1-5: 0.005 \\
2-5: 0,005 \\
3-5: 0,001 \\
4-5: 0,005\end{array}$ \\
\hline Haemorrhage & $\begin{array}{l}\text { Sham (1) } \\
\text { ASX } 10(2) \\
\text { ASX } 30(3) \\
\text { ASX } 100(4) \\
\text { Control (5) }\end{array}$ & $\begin{array}{c}0.88 \pm 0.64 \\
1.25 \pm 1.28 \\
0.63 \pm 1.06 \\
0.5 \pm 0.76 \\
1.88 \pm 0.83\end{array}$ & $<0,05$ & $\begin{array}{l}1-5: 0,041 \\
3-5: 0,012 \\
4-5: 0,006\end{array}$ \\
\hline Neutrophilic infiltration & $\begin{array}{l}\text { Sham (1) } \\
\text { ASX } 10(2) \\
\text { ASX } 30(3) \\
\text { ASX } 100(4) \\
\text { Control (5) }\end{array}$ & $\begin{aligned} 0.25 & \pm 0.71 \\
0 & \pm 0 \\
0 & \pm 0 \\
0 & \pm 0 \\
1.25 & \pm 0.89\end{aligned}$ & $<0.05$ & $\begin{array}{l}1-5:<0,001 \\
2-5:<0,001 \\
3-5:<0,001 \\
4-5:<0,001\end{array}$ \\
\hline $\begin{array}{l}\text { Thickness of the alveolar wall } \\
\text { and hyaline } \\
\text { membrane formation }\end{array}$ & $\begin{array}{l}\text { Sham (1) } \\
\text { ASX } 10(2) \\
\text { ASX } 30(3) \\
\text { ASX } 100(4) \\
\text { Control (5) }\end{array}$ & $\begin{array}{c}1.25 \pm 0.89 \\
1.5 \pm 0.53 \\
0.75 \pm 0.46 \\
1 \pm 0.53 \\
1.88 \pm 0.83\end{array}$ & $<0,05$ & $\begin{array}{l}2-3: 0,032 \\
3-5: 0,002 \\
4-5: 0,014\end{array}$ \\
\hline NF-к $\beta$ & $\begin{array}{l}\text { Sham (1) } \\
\text { ASX } 10 \text { (2) }\end{array}$ & $\begin{array}{c}13.5 \pm 6.82 \\
9.38 \pm 3.2 \\
55 \pm 10.69\end{array}$ & $<0.05$ & $\begin{array}{l}1-2: 0,024 \\
2-4: 0,036 \\
1-5:<0,001 \\
2-5:<0,001 \\
3-5:<0,001 \\
4-5:<0,001\end{array}$ \\
\hline 4-hydroxynonenal & $\begin{array}{l}\text { Sham (1) } \\
\text { ASX } 10(2) \\
\text { ASX } 30(3) \\
\text { ASX } 100(4) \\
\text { Control (5) }\end{array}$ & $\begin{array}{c}53.75 \pm 13.02 \\
70 \pm 8.86 \\
65 \pm 11.95 \\
75 \pm 10.69 \\
86.88 \pm 4.58\end{array}$ & $<0.05$ & $\begin{array}{l}1-2: 0,003 \\
1-3: 0,035 \\
1-4:<0,001 \\
1-5:<0,001 \\
2-5: 0,002 \\
3-5:<0,001 \\
4-5: 0,027\end{array}$ \\
\hline
\end{tabular}

\section{H\&E Staining}

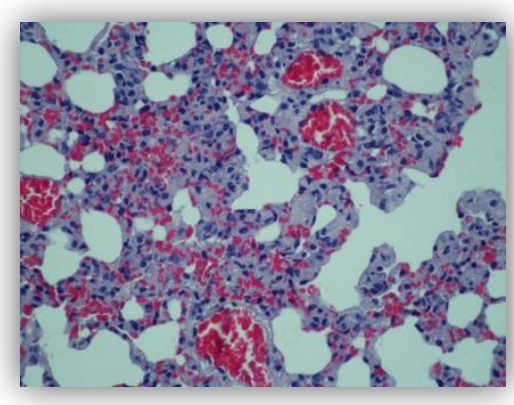

Alveolar congestion Score 2

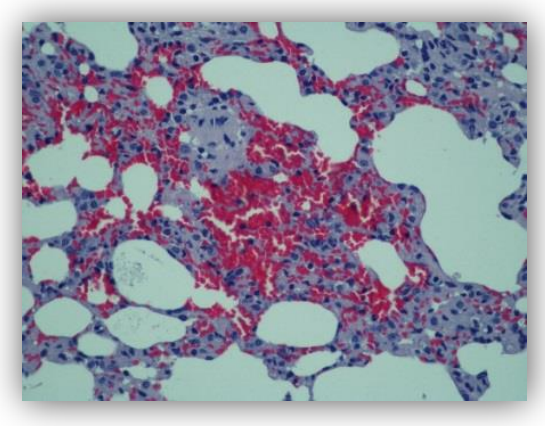

Haemorrhage Score 3 


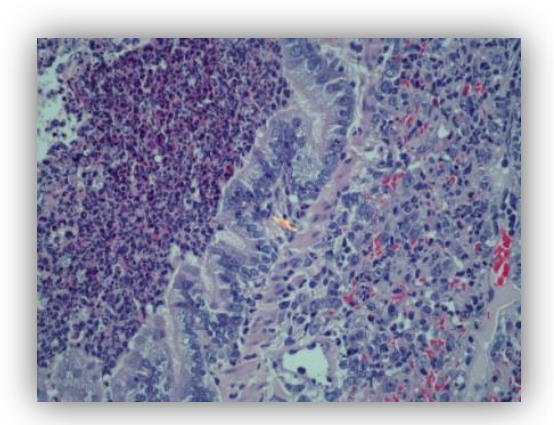

Neutrophilic infiltration Score 3

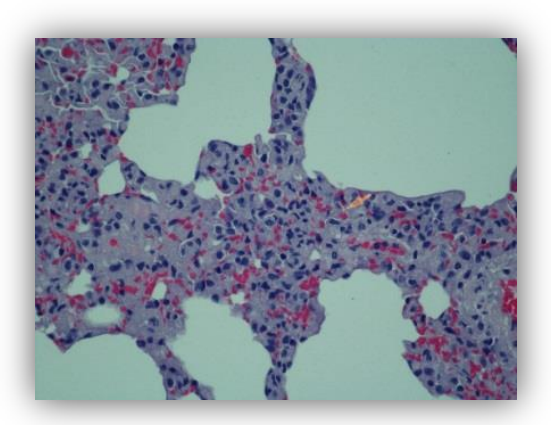

Alveolar wall thickness Score 3

Figure 1. Upper left: Example with alveolar congestion score 2: Congestion is observed in capillaries and venules in the alveolar wall (HE x 400). Upper right: Sample with bleeding score 3: erythrocytes are heavily involved in the alveolar wall and in the lumen (HE x 400). Lower left: A neutrophilic infiltration score of 3: neutrophilic infiltration is observed in the bronchial lumen (left half), in the alveolar wall and interalveolar area (right half) and in the bronchial epithelium (arrow) (HE $\mathrm{x}$ 400). Lower right: Example of alveolar wall thickness 3: pronounced thickening (arrow) in the interalveolar septum (HE $\mathrm{x}$ 400)

\section{Immunohistochemical analysis of $N F-\kappa \beta$ and 4-hydroxynonenal}

4-HNE and NF-к $\beta$ was detected in all animal samples. 4-HNE levels in sham group was significantly lower than control, ASX10, ASX30 and ASX100 groups $\mathrm{p}(<0,05)$, however 4 -HNE levels in control group was significantly increased than sham, ASX10, ASX30 and ASX100 groups $\mathrm{p}(<0,05)$. No difference between ASX10, ASX30 and ASX100 groups were found (Table 1) (Fig. 2).

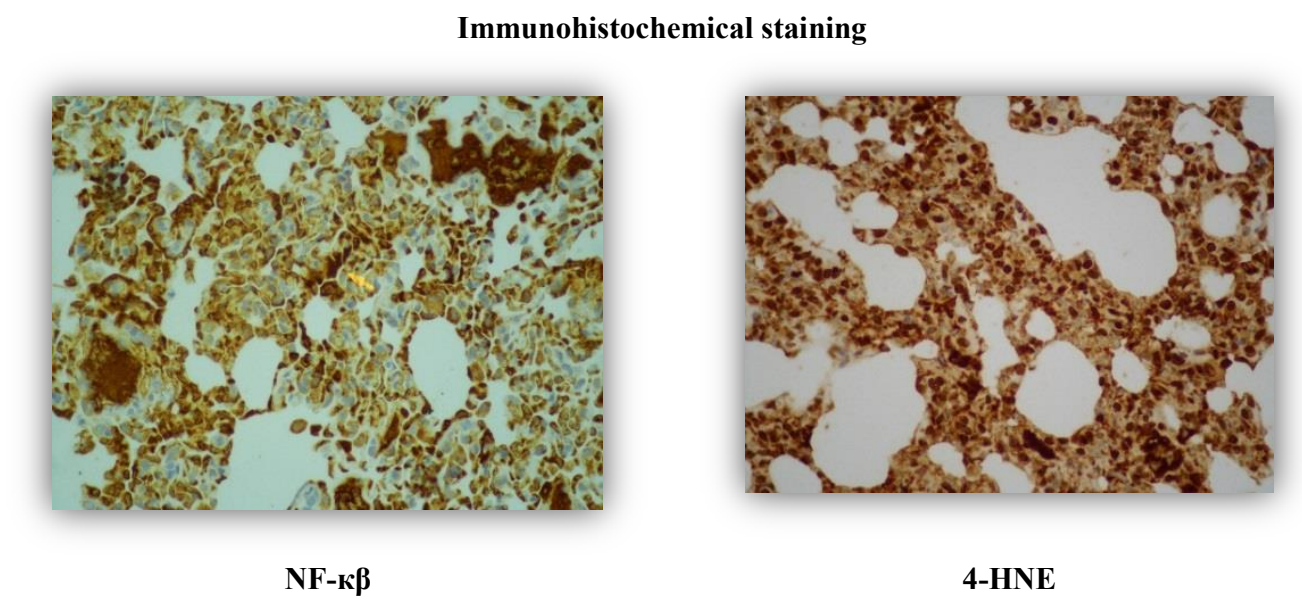

Figure 2. Example of NF kappa B staining of $70 \%$, nuclear and cytoplasmic staining is more common in the alveolar epithelium (x400), with 4-HNE staining of 50\% nuclear and cytoplasmic positivity is observed in the alveolar epithelium and interalveolar area $(\mathrm{x} 400)$.

NF-к $\beta$ levels in control group was significantly increased than sham, ASX10, ASX30 and ASX100 groups $\mathrm{p}(<0,05)$. Levels in ASX 10 group was significantly increased than sham and ASX100 groups $\mathrm{p}(<0,05)$. No difference between ASX10 to ASX30 groups were found. There were no statistically difference between sham,
ASX30 and ASX100 groups were found (Table 1) (Fig. 2).

\section{Biochemical Findings}

Proinflammatory cytokines TNF- $\alpha$, IL- 6 and IL$1 \beta$ levels in lung tissue decreased by astaxanthin treatment $(p<0,05) \quad($ Table 2). No difference 
detected between sham, ASX10, ASX30 and ASX100 groups. Although no difference detected on only IL-6 levels between ASX30 and control groups $(p=0,065)$. Oxidative stress marker MDA levels in lung tissue decreased by astaxanthin treatment $(p<0,05) \quad($ Table 2). No difference detected between sham, ASX10, ASX30 and
ASX100 groups. Glutathione reductase enzyme levels found significantly increased in control group than sham, ASX10, ASX30 and ASX100 groups $(p<0,05) \quad($ Table 2). No difference detected between sham, ASX10, ASX30 and ASX100 groups.

Table 2. Biochemical findings with statistical analyses

\begin{tabular}{|c|c|c|c|c|}
\hline & & Mean \pm Std. Dev. & $\mathbf{p}$ & Multiple Comparisons \\
\hline \multirow[t]{5}{*}{ TNF- $\alpha$} & Control (1) & $408.78 \pm 236.91$ & \multirow[t]{5}{*}{$<0.05$} & \multirow{5}{*}{$\begin{array}{l}1-2: 0,001 \\
1-3: 0,002 \\
1-4: 0,018 \\
1-5: 0,002\end{array}$} \\
\hline & Sham (2) & $188.68 \pm 74.34$ & & \\
\hline & $\operatorname{ASX10}(3)$ & $212.68 \pm 41.72$ & & \\
\hline & $\operatorname{ASX30}(4)$ & $262.14 \pm 47.74$ & & \\
\hline & $\operatorname{ASX100(5)}$ & $208.61 \pm 68.81$ & & \\
\hline \multirow[t]{5}{*}{ Glutathione Reductase } & Control (1) & $965.33 \pm 175.2$ & \multirow[t]{5}{*}{$<0,05$} & \multirow{5}{*}{$\begin{array}{l}1-2:<0,05 \\
1-3:<0,05 \\
1-4:<0,05 \\
1-5: 0,003\end{array}$} \\
\hline & Sham (2) & $857.51 \pm 127.99$ & & \\
\hline & $\operatorname{ASX10}(3)$ & $849.01 \pm 65.68$ & & \\
\hline & $\operatorname{ASX30}(4)$ & $838.8 \pm 47.02$ & & \\
\hline & $\operatorname{ASX100(5)}$ & $799.98 \pm 39.1$ & & \\
\hline \multirow[t]{5}{*}{ IL-6 } & Control (1) & $420.28 \pm 249.09$ & \multirow[t]{5}{*}{$<0.05$} & \multirow{5}{*}{$\begin{array}{l}1-2: 0,002 \\
1-3:<0,05 \\
1-5: 0,001\end{array}$} \\
\hline & Sham (2) & $169.34 \pm 107.55$ & & \\
\hline & ASX10 (3) & $259.3 \pm 121.93$ & & \\
\hline & ASX30 (4) & $275.66 \pm 150.45$ & & \\
\hline & $\operatorname{ASX100}(5)$ & $139.36 \pm 65.51$ & & \\
\hline \multirow[t]{5}{*}{ IL-1 $\beta$} & Control (1) & $220.77 \pm 60.44$ & \multirow[t]{5}{*}{$<0.05$} & \multirow{5}{*}{$\begin{array}{l}1-2:<0,001 \\
1-3:<0,001 \\
1-4:<0,001 \\
1-5:<0,001\end{array}$} \\
\hline & Sham (2) & $60.98 \pm 21.5$ & & \\
\hline & ASX10 (3) & $71.1 \pm 28.61$ & & \\
\hline & ASX30 (4) & $80.43 \pm 29.98$ & & \\
\hline & $\operatorname{ASX100(5)}$ & $61.94 \pm 22.66$ & & \\
\hline \multirow[t]{5}{*}{ MDA } & Control (1) & $127.09 \pm 73.08$ & \multirow[t]{5}{*}{$<0,05$} & \multirow{5}{*}{$\begin{array}{l}1-2: 0,01 \\
1-3:<0,05 \\
1-4: 0,018 \\
1-5: 0,01\end{array}$} \\
\hline & Sham (2) & $74.92 \pm 13.79$ & & \\
\hline & ASX10 (3) & $85.91 \pm 33.93$ & & \\
\hline & $\operatorname{ASX30}(4)$ & $79.18 \pm 24.68$ & & \\
\hline & $\operatorname{ASX100}(5)$ & $74.44 \pm 11.26$ & & \\
\hline
\end{tabular}

\section{Discussion and Conclusion}

Smoke inhalation injury leads to inflammatory process, acute respiratory distress syndrome (ARDS) and systemic inflammatory response syndrome (SIRS) due to proinflammatory cells merged in to the systemic circulation (17). The toxic particulates of smoke produce acute airways inflammation that can lead to oedema, mucosal damage, small airways obstruction, atelectasis, and respiratory failure. In addition, tissue oxygenation is impaired due to increased carboxyhemoglobin level. Development of oxygen hunger in tissues occurs due to hyper metabolic condition and direction of blood flow changes from intestines to muscle and soft tissues. As a result, bowel perforations and multiple organ failures can be seen. Cardiac dysfunction may develop due to impediment in oxygen transport and hypovolemia. Although, 
systemic antioxidant levels may decrease significantly. However, it is still a matter of debate as to why antioxidants, which are very important in protecting against oxidative stress injury, have decreased. It is thought that the levels of antioxidants are reduced because of transposition to immune active areas, dilution due to liquid treatment, inadequate intake and increase of disposal by biological fluids (18). It has been shown that vitamin C use in inhaled lung injury reduces the fluid requirement, oedema development and reduce the duration of mechanical ventilation. These results support the use of other antioxidant substances (such as vitamin E, alpha-gamma tocopherol, etc.) as supportive in the treatment of inhalation damage. As a matter of fact, alpha and gamma tocopherol have a positive effect on pulmonary functions and increased $\mathrm{PaO} 2$ : $\mathrm{FiO} 2$ ratio.

Astaxanthin is a xanthophyll carotenoid found in a variety of living organisms, including microalgae, fungi, seafood, and some birds such as flamingos and quails (20). Humans are unable to manufacture carotenoids, including astaxanthin, and therefore need to consume these in their diet. Astaxanthin is a potent quencher of reactive oxygen and nitrogen species, especially singlet oxygen. Many studies have reported using astaxanthin as an antioxidant (21-22).

In our study, morphological and histopathological changes of smoke inhalation injury in control group observed as similar as literature (19). Mortality prevented by performing intermittent smoke and oxygen exposure as described in literature (13). Increased neutrophilic infiltration, alveolar congestion, alveolar wall thickness and haemorrhage was observed in control group with respect to ASX30 and ASX100 groups in histopathologic examination. This difference between control and treatment groups are statistically significant $(\mathrm{p}<0,05)$. However, there is no difference in alveolar wall thickness and haemorrhage scores between control and ASX10 group.

Tissue 4-HNE levels is an important biomarker of oxidative stress. A small amount of 4-HNE is located in normal tissues but levels are elevated because of oxidative stress induced lipid peroxidation (23). In our study, lower ratio of tissue 4-HNE immunopositive area seen in all of the ASX treated groups than control group $(p<0,001)$. These findings indicates lower level of oxidative stress develops in ASX treated groups.

Literature review demonstrates that NF- $\mathrm{KB}$ pathway involved in the inflammatory lung injuries and some antioxidants have found positive effects on damage reduction $(24,25)$. $\mathrm{NF}-\kappa \mathrm{B}$ is a rapid response nuclei transcrip $\neg$ tion factor and two subunits were included in NF- $\kappa B$. NF- $\kappa B$ is located in the cytoplasm and is combined to the inhibitory unit inhibitory $\kappa \mathrm{B}(\mathrm{I} \kappa \mathrm{B})$. When $\mathrm{I} \kappa \mathrm{B}$ is phosphorylated by its kinase I $\mathrm{KB}$ kinase, it could translocate into nucleus to adjust gene transcription, including proinflammatory cytokines (26). In our study, lower ratio of nuclear NF- $\mathrm{KB}$ are seen in all of the ASX treated groups than control group $(\mathrm{p}<0,001)$. Thus, the anti-inflammatory and antioxidant effects of astaxanthin through suppression of $\mathrm{NF}-\kappa \mathrm{B}$ pathway in smoke inhalation injuries has showed by this study.

In our experimental model, TNF- $\alpha$, IL-1 $\beta$ and IL-6 levels were lower in the ASX treated groups than the control group. ASX 10 and ASX100 groups have significantly lower TNF- $\alpha$, IL- $1 \beta$ and IL-6 levels compare to control group. ASX30 group have significantly lower TNF- $\alpha$, IL-1 $\beta$ levels compare to control group. Suzuki et al. (27) showed that in the endotoxin-induced uveitis in mice, ASX suppressed TNF- $\alpha$ at an early stage and had anti-inflammatory effects. It is thought that ASX is the result of regulating the release of reactive oxygen species, although it is not yet established which way to suppress TNF- $\alpha$ (28). Xuefeng et al. (29) studied astaxanthins effects on ischemia/reperfusion induced renal injuries. Astaxanthin has been shown to reduce TNF- $\alpha$, IL-1 $\beta$ and IL-6 levels and have antiinflammatory and anti-apoptotic effects.

Glutathione reductase (GR) is an enzyme and catalyses the reduction of glutathione disulphide to the glutathione (GSH). Our study demonstrates that GR levels are significantly increased at control group than ASX treated groups $(p<0,05)$. Astaxanthin 
performs its antioxidant action by binding both free oxygen radicals and by inducing paroxonase-1 which is an antioxidant enzyme and increases intracellular GSH levels (30). Smoke inhalation injury induced antioxidant depletion results as activation and increase of GR levels in control group. ASX enhances GSH levels via paroxonase-1 activation so decreased GR levels were found on our experimental study. Malondialdehyde (MDA), a peroxide produced in the reaction of free radicals and polyunsaturated fatty acids in the cell membranes, indicates an intensified oxidative stress response, lipid peroxidation and tissue injury. We found MDA levels increased significantly in control group than ASX treated groups $(p<0,05)$, it proves astaxanthin has antioxidant effects.

\section{REFERENCES}

1. Gill P, Martin RV. Smoke inhalation injury. BJA Education 2015;15:143-8.

2. Shirani KZ, McManus AT, Vaughan GM, et al. Effects of environment on infection in burn patients. Arch Surg 1986;121:31

3. Demling Robert H. Smoke inhalation lung injury: an update. Eplasty 2008;80:e27

4. Walker PF, Buehner MF, Wood LA, Boyer NL, Driscoll IR, Lundy JB, Cancio LC, Chung KK. Diagnosis and management of inhalation injury: an updated review. Critical Care. 2015;19:351.

5. Dries DJ, Endorf FW. Inhalation injury: epidemiology, pathology, treatment strategies. Scandinavian Journal of Trauma, Resuscitation and Emergency Medicine 2013;21:1

6. Belli S, Basaran O, Ozdemir BH, Türkoğlu S, Karabay G, Kut A, Karakayali H, Haberal M. Protective role of simvastatin on lung damage caused by burn and cotton smoke inhalation in rats. Journal of Surgical Research. 2011;15;167:e283-90.

7. Han ZH, Jiang YI, Duan YY, Wang XY, Huang Y, Fang TZ. Protective effects of hydrogen sulfide inhalation on oxidative stress in rats with cotton smoke inhalation induced lung injury. Experimental and therapeutic medicine. 2015;10:164-8.

8. Prien T, Traber DL. Toxic smoke compounds and inhalation injury -a review. Burns Incl Therm Inj 1988;14:452-60.

9. Rehberg S, Maybauer M, Enkhbaatar P, Maybauer D, Yamamoto Y, Traber D. Pathophysiology, management and treatment of smoke inhalation injury. Expert Rev Respir Med 2009 ;3:283-97.

10. Davinelli S, Nielsen M, Scapagnini G. Astaxanthin in skin health, repair, and
From the histopathologic aspect, haemorrhage and alveolar wall thickness scores of ASX30 and ASX100 groups are lower compared to control group and no significant difference found between ASX10 and control groups. Astaxanthin administration from oral route may be more than $10 \mathrm{mg} / \mathrm{kg} / \mathrm{d}$ for histopathologicly positive results. Our results have demonstrated that astaxanthin use have a beneficial role in smoke inhalation injury accompanying $30 \%$ burn of rats. Thus, astaxanthin may represent a potential approach to prevent systemic response due to oxidative stress and inflammatory processes of smoke inhalation injury and $>30 \%$ burns.

disease: A comprehensive review. Nutrients. $2018 ; 10: 522$

11. Li J, Wang F, Xia Y, Dai W, Chen K, Li S, Liu T, Zheng Y, Wang J, Lu W, Zhou Y. Astaxanthin pretreatment attenuates hepatic ischemia reperfusion-induced apoptosis and autophagy via the ROS/MAPK pathway in mice. Marine drugs. 2015;13:3368-87.

12. Gilpin DA. Calculation of a new Meeh constant and experimental determination of burn size. Burns 1996;22:607.

13. Cetin C, Ozyilmaz M, Baycu C, et al. Effects of rolling inhibition on smoke Burns 2003; 29: 307.

14. Baxter CR, Shires T. Physiological response to crystalloid resuscitation of severe burns. Ann NY Acad Sci 1968;150:874-94.

15. Mikawa K, Nishina K, Takao Y, Obara H. ONO-1714, a nitric oxide synthase inhibitor, attenu-ates endotoxin-induced acute lung injury in rabbits. Anesth Analg 2003; 97: 1751-55.

16. Li Y, Yao JH, Hu XW, Fan Z, Huang L, Jing HR, Liu KX, Tian XF. Inhibition of Rho kinase by fa $\urcorner$ sudil hydrochloride attenuates lung injury in $\neg$ duced by intestinal ischemia and reperfusion. Life Sci 2011; 88: 104-109.

17. Toon MH, et al. Management of acute smoke inhalation injury. Critical Care and Resuscitation 2010;12:53.

18. Murakami K, Traber DL. Pathophysiological basis of smoke inhalation injury. News Physiol Sci 2003;18:125-9.

19. Hubbard GB, Langlinais PC, Shimazu T. The morphology of smoke inhalation injury in sheep. J Trauma 1991;31:1477.

20. Higuera-Ciapara I, Felix-Valenzuela L, Goycoolea FM. Astaxanthin: a review of its 
chemistry and applications. Crit Rev Food Sci Nutr 2006;46:185-196.

21. Pashkow FJ, Watumull DG, Campbell CL. Astaxanthin: a novel potential treatment for oxidative stress and inflammation in cardiovascular disease. Am $J$ Cardiol 2008;101:58D-68D.

22. Fassett RG, Coombes JS. Astaxanthin in cardiovascular health and disease. Molecules 2012;17:2030-48.

23. Mizuta $M$, Hirano $S$, Ohno $S$, et al. Expression of reactive oxygen species during wound healing of vocal folds in a rat model. Ann Otol Rhinol Laryngol 2012;121:804810.

24. Tian XF, Yao JH, Zhang XS, Zheng SS, Guo $\mathrm{XH}$, Wang LM, Wang ZZ, Liu KX. Protective effect of carnosol on lung injury induced by intestinal ischemia/reperfusion. Surg Today 2010; 40: 858-65.

25. Tian XF, Yao JH, Li YH, Zhang XS, Feng $\mathrm{BA}$, Yang $\mathrm{CM}$ and Zheng SS. Effect of nuclear factor kappa $B$ on intercellular adhesion molecule-1 expression and neutrophil infiltration in lung injury induced by intestinal ischemia/reperfusion in rats. World J Gastroenterol 2006; 12: 388-92.

26. Yao JH, Zhang XS, Zheng SS, Li YH, Wang LM, Wang ZZ, Chu L, Hu XW, Liu KX, Tian XF. Prophylaxis with carnosol attenuates liver injury induced by intestinal ischemia/reperfusion. World J Gastroenterol 2009; 14: 3240-45.

27. Suzuki Y, Ohgami K, Shiratori K, Jin XH, Ilieva I, Koyama Y, Yazawa K, Yoshida K, Kase S, Ohno S. Suppressive effects of astaxanthin against rat endotoxin-induced uveitis by inhibiting the NF- $\mathrm{KB}$ signaling pathway. Experimental Eye Research. 2006 ;82:275-81.

28. Lee SJ, Bai SK, Lee KS, Namkoong S, Na HJ, Ha KS, Han JA, Yim SV, Chang K, Kwon YG, Lee SK. Anti-Inflammatory. Moleculer Cell. 2003;16:97-105.

29. Qiu X, Fu K, Zhao X, Zhang Y, Yuan Y, Zhang S, Gu X, Guo H. Protective effects of astaxanthin against ischemia/reperfusion induced renal injury in mice. Journal of translational medicine. $2015 \mathrm{Dec}$;13(1):28.

30. Dose J, Matsugo S, Yokokawa H, Koshida Y, Okazaki S, Seidel U, Eggersdorfer M, Rimbach G, Esatbeyoglu T. Free radical scavenging and cellular antioxidant properties of astaxanthin. International Journal of Molecular Sciences. 2016;17:103. 